Univerzitet u Beogradu

Filološki fakultet

darko.ilin@yandex.com

\title{
RANA PREVODNA I KRITIČKA RECEPCIJA VINJETA IVANA CANKARA U SRPSKOJ SREDINI
}

Cilj ovog rada je da predstavi uslove u kojima se pojavilo prvo knjižno izdanje dela Ivana Cankara u srpskoj sredini, te da osvetli na koji način je ono bilo primljeno u kritici. Na početku rada biće reči o nastanku prve Cankareve knjige kratke proze pod naslovom Vinjete, a potom o prevodnoj recepciji njegove kratke proze u periodici. Središnji deo rada fokusiraće se na okolnosti oko srpskog prevoda Vinjeta kao deo serije Jugoslovenska biblioteka, kao i na ličnost prvog prevodioca Cankarevih dela. Na kraju rada će pažnja biti posvećena izrazito negativno intoniranoj kritici iz pera srpskog pesnika ranog modernizma, Jovana Dučića, te posednji deo rada predstavlja pokušaj razumevanja razloga takve kritike.

Ključne reči: Jugoslovenska biblioteka, književni prevod, Cankar, Vinjete, Dučić

Cankareva prva književna dela, kao što je to bio slučaj i sa većinom drugih autora, prvi put su ugledala svetlost dana u periodici, drugim rečima, Cankarev spisateljski put počinje još mnogo pre izlaska zbirke Vinjete objavljivanjem njegovih ranih proznih dela u slovenačkim časopisima. Međutim, početkom godine 1897. u pismu Franu Govekaru on po prvi put najavljuje da će mu za objavu u časopisu Slovenski narod poslati pet priča, koje naziva vinjetama. To je bio prvi put da je upotrebio taj naziv u sačuvanoj pisanoj korespodenciji, dok je pre toga svoju prozu određivao oznakom crtica (Bernik 408: 1976). Imajući u vidu da to nije čest i uobičajan način žanrovskog određenja jedne zbirke kratke proze, postavlja se pitanje zbog čega se Ivan Cankar odlučio upravo za taj termin. France Bernik raspravlja o tome dajući objašnjenje značenja izraza vinjeta i njegovog značaja za Ivana Cankara: 
Izraz ,vinjeta” od petnaestog veka označava na prvom mestu grafički ukras knjige, malu sliku ili crtež na rubu naslovne strane ili na kraju knjige, te na početku ili na kraju poglavlja. Pleteršnik opisuje npr. vinjetu kao „sličicu koja služi sa ukras". Tada je to bio izraz iz likovne i primenjene umetnosti, koja je Cankaru bila bliska, kojim Cankar imenovao svoju prvu zbirku kratke proze. (Bernik 408: 1976)

I potom navodi stav da se u razlogu Cankarevog imenovanja svoje proze vinjetama krije očigledna formalno-sadržinska sličnost sa pomenutim žanrom iz likovne umetnosti, a to je kratkoća i fragmentarnost.

Put od prvih vinjeta do objave istoimene zbirke trajao je dve godine, od početka 1897. do polovine 1899. godine kada je zbirka i objavljena. Janko Kos ukazuje na to da je Cankar veoma rigorozno i istančano birao prozna dela koja će u zbirku ući, o čemu svedoči i njegova korespodencija, a on takođe napominje da istovremeno sa nastajanjem njegovih Vinjeta, nastaju i crtice koje je moguće označiti kao njegove rane radove, nastale pod uticajem evropskog i francuskog realizma. Međutim, uprkos istom vremenu nastanka, moguće je stilski razlučiti između tekstova koji su ušli u Cankarev izbor vinjeta i onih koji su predstavljali širi izbor, ali u samu zbirku nisi bili uključeni, od onih koji nisu ni bili planirani za objavu pod zajedničnim imenom Vinjete, a nastajale su istovremeno sa njima (Kos 1969: 338-342) U svetlu načina na koji je bilo primljeno prvo objavljeno delo Ivana Cankara, zbirka poezije pod naslovom Erotika, važno je napomenuti da je recepcija njegovih Vinjeta bila umnogome blaža i pozitivnija u odnosu na način na koji je slovenačka javnost primila zbirku njegove erotske poezije.

Recepcija Cankarevih Vinjeta u srpskoj sredini došla je za uslove toga doba veoma brzo nakon objave, naime prvi prevod pojedinačne priče iz Cankarevih Vinjeta pojavio se u periodici i to u Brankovom kolu 1901. godine, potom i u mostarskoj Zori. U publikaciji Ivan Cankar v prevodih objavljenoj godine 1977. nalazi se spisak prevoda dela Ivana Cankara na strane jezike, koji su do tada bili objavljeni ${ }^{22}$, te postoji

\footnotetext{
22 v1901: Jedna sama noć. [Ena sama noč.] Prev. Iv[ković Miloš]. - Brankovo kolo (Sremski Karlovci) 7/1901 str. 714-18. [ćir], Mrtvi neće. [Mrtvi nočejo.] Prev. Miloš Ivković. - Zora (Mostar) 6/1901 str. 210-211. [ćir], Putovanje Nikole Nikića. [Potovanje NIkolaja Nikiča.] Prev. Miloš Ivković. - Zora (Mostar) 6/1901 str. 293-314. [ćir]. 1902: Pred ciljem. Prev. M[iloš] Ivković. - Kolo (Beograd) knj III 1902. str 207-15 [ćir], Glad. Prev. anon. - Svjetlo (Karlovac) 17/1902 br. 20 Ti si sam kriv! Prev. anon. - Svjetlo (Karlovac) 17/1902 br. 21, Marta i Magdalena. [Marta in Magdalena.] Prev. A. K[učera]. - Svjetlo (Karlovac) 17/1902 br. 24, Judin pozdrav. [Judežev pozdrav.] Prev. Kučera. Svjetlo (Karlovac) 17/1902 br. 26. 1905: Gospar Antorije. [Signor Antonio.] Prev. Vmr.
} 
verodostojan spisak dela koja su bila prevedena na srpskohrvatski jezik do 1906. godine, uz navođenje detaljnih bibliografskih podataka o prevodiocima, izdanjima i časopisima u kojima su dela objavljena. Iz ovoga se može zaključiti da je prevodna recepcija Cankarevih Vinjeta bila veoma živa, te da je interkulturni dijalog između Slovenaca i drugih južnoslovenskih, uskoro i jugoslovenskih naroda bio intenzivan.

Izdanje koje je primarni predmet ovoga rada, zapravo je izdanje izbora iz Vinjeta u prevodu Miloša Ivkovića iz 1907. godine. Neke od vinjeta, koje se nalaze unutar ove knjižice, već su bile prevedene i objavljene u periodici. To je slučaj sa crticom Jedna usamljena noć i Mrtvi neće, dok su ostale vinjete (Matilda, Original, Moja fijoka, $U$ mrtvu jesen, i O čoveku koji je izgubio uverenje) prevedene za potrebe objave ove knjige. Značajno je istaći i specifičnost ovog izdanja, koje se ogleda u tome da se na kraju same knjige nalazi odlomak iz vinjete Jedna usamljena noć u originalu, na slovenačkom jeziku, tako da su tadašnji čitaoci imali priliku da se upoznaju sa Cankarevim stilom iz prve ruke, te da imaju direktan kontakt sa slovenačkim jezikom, što je još jedna osobina ovog izdanja kao interkulturnog posrednika.

Ličnosti prevodioca Cankarevih Vinjeta valja posvetiti više pažnje. Na knjizi potpisan samo kao M. Ivković, nije po struci bio primarno prevodilac, već ligvista i prosvetni radnik, Zoran Živković Hristić bavio se podrobnim istraživanjem arhivske građe o njegovom životu i delu ${ }^{23}$. U njegovoj biografiji navedeno je da je vladao slovenačkim

- Brankovo kolo (Sremski Karlovci) 11/1905 str. 431-434. [ćir], Nina. Prev. Lj. Zlatarić. - Brankovo kolo (Sremski Karlovci) 11/1905 str. 434-442. [ćir]. 1906: Krivica. [Prev. Karlo Cankar.] - Hrvatski dnevnik (Sarajevo) 1/1906 (24. XII) br. 294.

${ }^{23}$ Милош Ивковић (3.5.1880-14.5.1950) рођен је у Осјеку и због положаја свог оца у аутроугарској коњици, као дете се доста селио. Основну школу учио је у Осјеку, Шиду и Љубљани, гимназију у Сремским Карловцима, Сушаку и поново Осјеку. Године 1901. сели се у Београд и уписује Велику школу, на којој дипломира на смеру Словенска филологија с књижевношћу 25. јула 1906. године. Од 1907. до 1911. године ради као предавач у неким београдским гимназијама, а након неуспешног покушаја да постане асистент за словенску филологију 1910. добија прилику да годину дана 1911/12. проведе на усавршавању у Француској. Потом бива премештен у Скопље, где су га затекла оба балканска и Први светски рат, а након Првог светског рата радио је као хонорарни професор на Филозофском факултету у Скопљу, конзул краљевине СХС у Риму, један од оснивача Прилога за књижевност, језик, историју и фолклор, технички секретар Лексикографског одсека Српске краљевске академије. Осим што је био талентован проучавалац језика (дијалектологија, лексикографија...), био је и полиглота и преводилац. Његов најпознатији превод је превод романа Младић Ф. М. Достојевског, који се у деловима и изборима прештампава и у овом веку. У његовој рукописној 
jezikom (Живковић Христић 2011: 106), što je očigledno iz njegovog prevoda, koji nije sa svih aspekata savršen, ali je većinom tačan i verodostojan. Pomenuti prevodi Cankarevih dela predstavljaju jedine njegove poznate prevode književnih dela sa slovenačkog jezika.

Treba pomenuti i to da je Ivković opremio srpsko izdanje Vinjeta predgovorom, u kojem na početku kontekstualizuje Cankarev dotadašnji književni rad unutar sistema slovenačke književnosti realizma. Cankaru priznaje da je u slovenačku književnost doneo: „ослобођење од старих и извешталих форама, фраза и идеја, усвајање нових погледа на живот и душу, слободу и самосталност у стварању" (Ивковић 1907: 5). Iz predgovora se može nedvosmisleno zaključiti da je Ivković bio upoznat ne samo sa savremenom književnom situacijom u Sloveniji već i da je znao za nesrećne okolnosti oko objavljivanja Cankareve Erotike, ali on donosi i pregled Cankarevog stvaralaštva do 1905. godine, što na osobit način pokazuje da je prevodilac bio upućen u sasvim savremenu književnu produkciju na slovenskom jugu. O samim Vinjetama je napomenuo da se u njoj opažaju sve osobine Ivana Cankara kao noveliste, koje je označio kao „магловитост, фантастичност, парадокси, чулност, иронија, нежност, сентименталност, и стилистички ефекти" (Ивковић 1907: 7).

Treba imati u vidu i to, da je ova knjiga objavljena kao prva knjiga prvog kola u seriji pod nazivom Jugoslovenska biblioteka, što ukazuje na postepeno kulturno zbližavanje južnoslovenskih naroda pred samo formalno ujedinjenje u Kraljevinu Srba, Hrvata i Slovenaca. Važno je pomenuti da je sama biblioteka imala odjek u javnosti, te da ju je srpski kritičar i gimnazijski profesor Jovan Živojnović s početka XX veka odredio kao veoma važan kulturni projekat ${ }^{24}$. Jugoslovenska biblioteka prepoznata je i u slovenačkoj javnosti kao pomena vredan poduhvat. U časopisu Dom in svet nalazi se sažeto obaveštenje o izdavanju Cankare-

заоставштини пронађен је и незавршени превод Хиладу и једне ноћи. (Живковић Христић 103-107)

24 „Када се сетимо да је књижевност и у осталих просвећених народа прва помицала напредне и спасоносне мисли за народни напредак и просветни и политични, и погледамо на разривене одношаје међу већином браће јужних Словена, на и њихово јадно стање изнутра, онда ову мисао, коју заступа Југословенска библиотека морамо из свег срца поздравити. Она иде за тим да упозна упоредно српске читаоце са најнапреднијим производима књиженим у Словенаца, Хрвата, Бугара и Срба и да тиме изазове поштовање према просвети и народној индивидуалности појединих огранака Словена на југу, које ће нас одвести споразуму у узајамној љубави место привлачно начесто набујале мржње досадашње” (Живојновић 1908: 72) 
vih Vinjeta u ovoj biblioteci, dok se u časopisu Ljubljanski Zvon nalazi nešto sadržajniji prikaz namena i ciljeva Jugoslovenske biblioteke, u kojem takođe centralno mesto zauzima kratka pozitivna recenzija izdanja Vinjeta (Tominšek 1907: 507)

Stručnjaci poput Jovana Živojnovića su, dakle, uspeli da prepoznaju značaj ovog projekta, jednog od prvih te vrste, i da u njemu vide sredstvo interkulturnog dijaloga među Južnim Slovenima. Međutim, i on pokazuje istančan osećaj za osobine Cankarevog stvaralaštva - o Cankaru i njegovim Vinjetama piše:

У најближем додиру са западом видимо, како се је Словенац највише модернизовао. Иван Цанкар је представник чистога индивидуализма. У њега видимо развијену јединку, која са својим страстима ступа у неравну борбу са заводљивим светом. Јагма за личним уживањем по сваку цену јесте истакнута црта тог модернога човека, у којега се тек после гомиле оборених жртава јавља опорина осећања гриже савести са почињених грехова, која га уздиже на филофовско посматрање безбојнога света под собом, те јетко тражи по њему изгубљено уверење људи (Живојновић 1908: 72).

Živojnivić se pokazuje kao kritičar koji razume Cankarevu modernost u savremenom kontekstu, a posebno za osećaj modernog čoveka, kakav je prisutan u Cankarevim Vinjetama. Naime, on u ovom napisu uspeva da na veoma poetičan način istakne suštinu koja je utkana u ranu prozu slovenačkog pisca.

Za moj rad najznačajniju kritiku napisao je srpski pesnik ranog modernizma Jovan Dučić. O Dučiću kao književnom kritičaru nije mnogo pisano, jer, kako zaključuje Sanja Macura, on je svojim pesničnim i proznim delima zasenio ostale aspekte svoga stvaralaštva (Мацура 2003: 9). Pri kontekstualizaciji Dučićevog kritičarskog rada važno je pomenuti neke premise, poput one, da je smatrao da kritičar da bi napisao dobru kritiku, mora umeti da napiše nešto i o samom predmetu dela, te da je pisac najbolji kritičar. Odnosno, da nije bio pobornik čisto naučne već stvaralačke kritike, te da je smatrao da je kritičar u isto vreme i čitalac $\mathrm{i}$ autor, te da mora biti vešt $\mathrm{u}$ obema disciplinama $\mathrm{i}$ da je svojim kritičarskim radom zapravo preispitivao postojanje i smisao književne kritike (Мацура 2003: 5-7).

U listu Politika 17. maja 1908. godine Dučić je objavio kritiku Cankarevih Vinjeta, koja je bila izrazito negativno intonirana. Kritiku započinje opštom refleksijom o formi vinjeta, ističući njihovu žanrov- 
sku neodređenost i nastojanje da u sebe upiju što više žanrova, ali takođe ističe da je pokušaj da prevaziđu jedan žanr rezultirao neuspešno. On dodaje da su Vinjete „нешто равнодушне и пресне, и врло књишке, и врло из главе” (Дучић 1969: 287). Segment se završava poetski intoniranom rečenicom: „ово су неке вештачке фигуре прављене на парчадима леда" (Дучић 1969: 287). Na semantički povlašćenom, ili, na ovde opravdanom mestu novinskim rečnikom rečeno, udarnom mestu, na početku kritike, Dučić ističe formalnu hibridnost Cankarevih Vinjeta kao njihovu negativnu osobinu, što se može protumačiti kao ostatak larpurlartističkih težnji i favorizovanja otmenije književnosti.

U narednom segmentu ukazuje na izvesnost postojanja nekih dobrih momenata, međutim njih ne pripisuje samoj Cankarevoj invenciji, već ukazuje na moguće uzore u Tvenu ili Multatuliju. Na takav način se relativizuje pozitivan komentar o Cankarevim Vinjetama i umanjuje vrednost i samosvojnost originalnog stvaralačkog impulsa slovenačkog autora.

Sledeći deo kritike fokusira se na pojedinačne vinjete, i to najčešće na aspektima koje posmatra kao neuspele: U vinjeti pod naslovom Jedna sama noć Dučić zamera Cankaru na nedostatku izgrađene atmosfere, te da ovakva fabula ne odgovara pojmu ,велике трагичне истине" koja bi, kako smatra Dučić, trebalo da postoji pred pripovedačem (1969: 288). Čini se da Jovan Dučić Cankaru u najvećoj meri zamera neadekvatnu atmosferu koja je prisutna u njegovoj kratkoj prozi, on uočava nedoslednosti po pitanju izgradnje unutrašnjeg emotivnog sveta junaka. Dodaje i da je u Vinjetama „опис тако убог да ништа не подсећа на једну приповетку ни на један талент” (1969: 288). Ovakav kraj važan je zbog onoga što Dučić iznosi na začetku kritike. Naime, on naizgled priznaje Cankara kao autora koji je stvorio modernu slovenačku novelu, kao i to da je Ivan Cankar možda jedan od najboljih jugoslovenskih pripovedača. Međutim, na tom mestu ističe da je književni proizvod nalik na Vinjete neverovatan za pripovedača, za kakvog važi Cankar. Tako i završna rečenica implicitno donosi Dučićev stav po pitanju opravdanosti Cankareve reputacije, ali i njegovog književnog talenta.

U sledećem segmentu Dučić se nakratko osvrće na druge vinjete u zbirci, jednu karakteriše kao dosta jevtinu literaturu sa ovlašnim efektom na kraju, drugu kao više dosetljivost nego duhovitost, kao neiskrenu ili staru filozofiju i slično (1969: 288). U nastavku podvlači upravo neadekvatnost ili neiskrenost atmosfere i sveta koji Cankar gradi u svo- 
jim delima, koja mu se čini knjiškom i artificijelnom. Međutim Dučić uz iznošenje kritika uspeva i da pokaže poetičnost svog jezika, što ide u prilog njegovoj tezi o piscu kao kritičaru.

U poslednjem segmentu svoje kritike o Vinjetama Jovan Dučić daje svojevrsni zaključak svog promišljanja o zbirci. Smatra da je ovim prevodom učinjena nepravda srpskom čitaocu, odnosno krajnje anatemiše pokušaj približavanja Vinjeta Ivana Cankara srpskoj publici, ali ne isključuje u potpunosti mogućnost da neko drugo delo bude bolji izbor, da bi neko drugo delo na bolji način pokazalo stvaralačke mogućnosti slovenačkog pisca. Dučić izriče i pohvalu prevodiocu, međutim ističući da ni darovit prevodilac, kakvim posmatra Ivkovića, nije u mogućnosti da popravi već loše delo i ,дадне више израза овим сухим и сивим стварима". Na samom kraju zaključuje da su Vinjete delo pisano bez svake emocije, pa i one izmišljene (1969: 289)

Imajući u vidu da je Dučić izneo ovako oštru kritiku, anatemišući rano Cankarevo stvaralaštvo, postavlja se pitanje zbog čega se to dogodilo. Iz samoga teksta se odgovor ne može nazreti jer je evidetno da je Dučić poznavao status kakav Cankar već tada uživa u slovenačkoj književnosti, te je nejasno iz kog je razloga implicirao da je takav status neopravdan. Odgovor možda može ležati u samom izboru vinjeta, koje su ušle u korpus prevedenih u ovoj knjizi, jer svaki izbor predstavlja ponovnu rekontekstualizaciju same zbirke, koja ipak u celosti ima svoje unutrašnje ustrojstvo. Možda bi situacija bila drugačija, da je prevodilac u svoj izbor uneo vinjetu Glad, koja je na poetski, ali i eksplicitan način raspravlja sa tradicijom, ili Epilog, koji na drugačiji način uspostavlja dijalog sa slovenačkom javnošću i njenim horizontnom očekivanja, suprotstavljajući mu jedan moderniji pogled na svet, te sada ta vinjeta predstavlja manifest slovenačke moderne.

Upoređujući poetike Jovana Dučića i Ivana Cankara, primećuje se da su delili slične poetičke stavove svojstvene piscima moderne, iz čega se sa jedne strane može zaključiti da je Dučić: „начином на који је писао своју критику и оним што је у њој написао, припадао оном истом кругу коме се интимно супротстављао, више из личних него из принципијелних разлога, оном колу српских ${ }^{25}$ интелектуалаца који су полазили од тога да пут у литературу води преко Европе" (Протић 1979: 30). Sa druge strane, razlog može i zaista ležati u nepodudaranju stilskih horizonata kritičara i stvaralačkih domašaja Ivana Cankara, što može značiti da je Cankareva rana proza zaista još uvek

\footnotetext{
${ }^{25}$ U ovom slučaju jugoslovenskih.
} 
stilski nesavršena i predstavlja tek korak prema njegovom zrelijem i vrednijem opusu. Ali, razlog može biti u tome što je Ivan Cankar u svojim Vinjetama doneo nešto sasvim novo, drugačiju formu ranog modernizma, koji nije počivao na temeljima koji su Jovanu Dučiću bili bliski, te da je ta neiskrena i knjiška atmosfera zapravo korak napred prema nekim kompleksnijim tendencijama kako u predstavljanju unutrašnjeg života likova tako i u izgradnji drugačijeg književnog sveta.

\section{Literatura}

Зоран ЖИВКОВИЋ ХРИСТИЋ, 2011: Милош Ивковић, његов животни пут, стваралаштво и рад у „Друштву за проучавање ослобођених српских области“" у Скопљу 1915. године, Варgарски зборник 8, 103-134.

Иван ЦАНКАР, 1907: Вињетее. Београд: Књижарница Боже О. Дачића.

Јован ДУЧИЋ, 1969: Моји сайуйници, Сабрана дјела, Сарајево: Свјетлост

Јован ЖИВОЈНОВИЋ, 1908: Југословенска библиотека. Лейойис Майице срйске 84, 249, 3, стр. 71-73, preuzeto sa http://digital.bms.rs/ ebiblioteka/publications/view/31/numid:5123 (23.5.2019)

Милош ИВКОВИЋ, 1907: Предговор, у Вињетее. Београд: Књижарница Боже О. Дачића.

Предраг ПРОТИЋ, 1979: Писци као критичари пре 1. светског рата, у Српска књижевна критика, књига XII, Нови Сад: Матица српска.

Сања МАЦУРА, 2003: Јован Дучић као књижевни критичар. Бања Лука: Филозофски факултет. Необјављена магистарска теза.

France BERNIK, 1976: Cankarjeva vinjetna črtica. Sodobnost 24, 5, preuzeto sa http://www.dlib.si/?URN=URN:NBN:SI:DOC-WF51DJB4 (26.5.2019)

Ivan Cankar v prevodih. [Zbornik Društva književnih prevajalcev Slovenije]. Murska Sobota: Društvo književnih prevajalcev Slovenije, 1977.

Josip TOMINŠEK, 1907. Jugoslovanska biblioteka - Cankarjeve »Vinjete«. Ljubljanski zvon, letnik 27, številka 8. preuzeto sa http://www.dlib. si/?URN=URN:NBN:SI:DOC-H9DOCQ38 (18.5.2019)

Pavle Ratko JOVIĆ, 2019: Prvi Srbski Prevodi Cankarjevih Del 19001940. Slavistična Revija 67 (1), 115-19. preuzeto sa https://srl.si/ojs/srl/article/ view/2019-1-2-3 (28.5.2019) 


\title{
EARLY RECEPTION OF TRANSLATED LITERARY TEXTS AND CRITICAL RECEPTION OF IVAN CANKAR'S VINJETE IN SERBIAN ENVIRONMENT
}

\begin{abstract}
Summary:
The aim of this paper is to present the circumstances in which the first book of Ivan Cankar was published in Serbia, and to display the way it was percieved by the critics. Topic of the first part of this paper will be about the way how Cankar's first book of short stories came to be. Vinjete is a collection of carefully chosen short stories that incorporated moderistic and symbolist elements into realist prose. Some of the short stories have been translated and published in Serbian literary magazines by 1907. Vinjete was chosen to be translated into Serbian and published as a part of Jugoslovenska biblioteka in order to present the works of other South Slavic literatures to the Serbian public. Therefore, the next segment of the paper was about the reception of that cultural project from the intercultural aspect. Critical work of Jovan Dučić, a Serbian symbolist poet, was dicsussed in the end of the paper, because he wrote a very negative critic on Cankar's Vinjete. The end of the paper tries to come to a conclusion about the reason of that negative response to the work of Ivan Cankar.
\end{abstract}

Key words: Jugoslovenska biblioteka, literary translation, Cankar, Vinjete, Dučić 